\title{
A Study of Histopathological Spectrum of Ovarian Neoplastic and Non-Neoplastic Lesions at Teaching Hospital, Ahmedabad
}

\author{
Piyush Ashokbhai Patel, Deval Narendrakumar Patel*, Mona Manubhai Patel and Jignasa Nathalal Bhalodia \\ Department of Pathology, GMERS Medical College and Sola Civil Hospital, Ahmedabad, India
}

\begin{abstract}
Background: Ovarian carcinoma is one of the most common gynecologic cancers that ranks third after cervical and uterine cancer. ovarian lesions are neoplastic and non neoplastic and many neoplastic lesions are asymptomatic and possess great challenge to the gynecological oncologist.

Aims \& Objectives: To analyze frequency, age distribution and histopathological spectrum of ovarian lesions at teaching hospital, Ahmedabad.

Materials \& Method: This study was undertaken between period of 1st January 2018 to 29th February 2020 at Department of Pathology, GMERS Medical college, sola, Ahmedabad. H and E stained slides were examined by light microscopy and histopathological type of lesions were classified according to World Health Organization(WHO) classification -2014..

Results: There were total 182 cases of ovarian lesions. 56(30.76\%) cases are neoplastic, among them only $6(10.71 \%)$ were malignant. Surface epithelial tumor( $\mathrm{n}=27$ cases, $48.21 \%$ ) were most common neoplastic lesion while sex cord stromal tumor(n=8 cases, $14.29 \%)$ were least common. Most common age group affected for neoplastic lesions was 31-40 years.

Conclusion: We found that ovarian lesions affect wide variation of age starting from 11 years young patient to 65 years old patients. Non neoplastic lesions were almost double in prevalence than neoplastic lesions. Histopathological analysis according to WHO classification reveal that surface epithelial tumors and germ cell tumors were forms the majority of neoplastic lesions.
\end{abstract}

\section{Keywords: Ovarian Lesion, Surface Epithelial Tumor, Germ Cell Tumor}

\section{Introduction}

The ovaries are paired intra-pelvic organ of the female reproductive system. The term 'Ovary' was introduced in the $17^{\text {th }}$ century. Even Shushruta has described ovarian neoplasms in his book "Shushruta and ayurveda'. [1] Ovarian neoplastic and non-neoplastic lesions present a great challenge to gynecological oncologist. Certain nonneoplastic lesions of the ovary often form a pelvic mass and potentially mimic an ovarian neoplasm. Their proper diagnosis and classification are therefore important to allow appropriate therapy. ${ }^{[2]}$ Ovarian tumors are one of the major health problems faced by clinicians. Ovarian carcinoma is one of the most common gynecologic cancers that ranks third after cervical and uterine cancer. ${ }^{[3]}$ Recent improvement in patient survival in developed countries is attributed to an earlier stage at diagnosis.

Ovarian tumors are often difficult to detect until they are advanced in stage or size, as symptoms are vague and insidious. ${ }^{[4]}$ Identification of various histologic patterns of ovarian tumors is important for diagnosis as well as prognosis. ${ }^{[1]}$ Benign conditions and some non neoplastic conditions are common during reproductive years while malignant ones tend to occur during perimenopausal and post menopausal age. Incidence of ovarian cancer is higher in postmenopausal, unmarried and low parity women. Pregnancy (especially if before age 25 years) and use of oral contraceptives are associated with a diminished risk. $[19,20,21,22]$ Because of complexity in structure of ovary owing to its unique embryological development, there are various classification schemes for ovarian neoplasms. However, The World Health Organization Histological Classification of ovarian tumors separates ovarian neoplasms according to the most probable tissue of origin: surface epithelial tumors $(65 \%)$, germ cell tumors $(15 \%)$, sex cord-stromal tumors $(10 \%)$, metastatic tumors $(5 \%)$ and miscellaneous tumors.

Surface epithelial neoplasms are further classified according to cell type (serous, mucinous, endometrioid, clear cell, transitional cell and epithelial- stromal) and degree of atypia (benign, borderline or malignant) ${ }^{[5]}$. Screening for ovarian cancers is aided by serum tumor markers like Alpha fetoprotein, Lactate dehydrogenase, Cancer Antigen 125, Placental Alkaline Phosphatase and radiodiagnostic techniques like Ultrasonography, Computed Tomography, Positron Emission Tomography scan and Magnetic Resonance Imaging.

More recently, development of techniques like image guided Fine Needle Aspiration Cytology, fluid cytology 
have helped immensely in early diagnosis of ovarian carcinomas. ${ }^{[6]}$ Intraoperative frozen section evaluation is crucial for determining the required extent of surgery, that is, cystectomy for benign tumors, oophorectomy or limited surgical removal for borderline tumors in younger patients to preserve fertility or extensive surgical removal for ovarian carcinomas. Touch imprint smears also aids the diagnosis and helps to differentiate between benign and malignant condition.

Present study was carried out with an aim to derive distribution, common age presentation and histopathological spectrum of various nonneoplastic and neoplastic lesions of ovary.

\section{Materials and Methods}

This study was undertaken using existing patient data retrieved from the registers and records of the histopathological laboratory, Department of Pathology, GMERS Medical College and hospital, Sola, Ahmedabad. A total of 182 ovarian specimens were studied for histopathological evaluation from $1^{\text {st }}$ January 2018 to $29^{\text {th }}$ February 2020, either as solitary specimens or as part of total abdominal hysterectomy (TAH) specimens.

Relevant clinical information regarding the age of patients, clinical features, radiological findings and provisional diagnosis were obtained. Gross examination of received specimen was done for various parameters like size, external surface, and consistency and cut sections with contents of cyst. The tissues were processed by routine paraffin techniques of tissue processing and sections stained with Haematoxylin and Eosin were taken for microscopic examination. The non-neoplastic and neoplastic lesions from representative sections were studied and classified according to World Health Organization (WHO) classification 2014. Acquired data were tabulated and analyzed.

\section{Results}

Out of the total 182 ovarian lesions 126(69.23\%) were nonneoplastic and 56(30.76\%) were neoplastic lesions. 56 neoplastic lesions are further classified in benign (48 cases, $85.72 \%$ ), borderline (02 cases, $3.57 \%$ ) and malignant lesions (06 cases, $10.71 \%$ ). The distribution of the cases amongst these categories is given in Table 1.

Non neoplastic lesions are common in 21-30 years of age group while the most common age group for all ovarian benign neoplastic lesions was found to be 31-40 years followed by 21-30 years, i.e, reproductive age group while Malignant ovarian neoplasm is mainly found in age more than 40 years. (table 2 )
Out of total 126 non neoplastic lesions most common lesion was simple serous cyst 49 (38.88\%), followed by chocolate cyst $35(27.77 \%$ ) and Corpus luteal cyst $16(12.69 \%)$ Whereas least common was Developmental cyst and nonspecific oophoritis, One case $(0.79 \%)$ of each reported. 5 cases(3.96\%) show normal histology.

Out of total 56 neoplastic lesions, 27 cases (48.21\%) were of surface epithelial tumors, 21 cases $(37.5 \%)$ were of germ cell tumors, 8 cases $(14.29 \%)$ were of sex cord stromal tumors [chart 1].

Out of 27 cases of surface epithelial tumors, 23(85.18\%) were benign, $2(7.41 \%)$ cases were borderline and $2(7.41 \%)$ were malignant tumors. Serous cystadenoma (9 cases,39.13\%) are most common benign neoplasm of surface epithelial tumors. There are 2 cases of borderline surface epithelial tumors, 1 case was of seromucinous type and 1 case was of mucinous type. There are 2 malignant surface epithelial tumors, 1 case was seromucinous type cystadenocarcinoma and 1 case was endometroid carcinoma [figure 2].

We found total 21 germ cell tumors, 20 cases (95.24\%) were benign and 1 case $(4.76 \%)$ was malignant. Out of total 20 benign cases, 19 cases (95\%) were Mature cystic teratoma while one was Mature solid teratoma which was associated with gliomatosis peritonei [figure 4]. Malignant case was of a dysgerminoma [figure 1].

Total 8 cases of sex cord stromal tumors are reported. Out of them, 05(62.5\%) were benign and 03 (37.5\%) were malignant. In benign lesions fibroma comprised of $50 \%$ of cases while granulosa cell tumor adult type [Figure 3] comprised of all the malignant cases.

\section{Discussion}

Ovarian cancer is the second leading cause of mortality among all gynecological cancers. ${ }^{[7]}$ Due to similar clinical presentations, there is confusion in the diagnosis of nonneoplastic and neoplastic lesions of ovary although it is diagnosed as a mass or cystic lesion on ultrasonography and hence removed prophylactically in routine oophorectomies and hysterectomies. ${ }^{[8]}$

In present study, total 182 ovarian specimens were received in our pathology department, Out of which 126(69.23\%) cases were non neoplastic lesion while 56(30.76\%) were neoplastic lesion. This result is comparable with the Indian study done by Sawant and Mahajan et al and study in Nepal done by Tadayon $\mathrm{M}$ et al in which they got $70 \%$ and $61 \%$ non neoplastic lesions and 30\% and 39\% neoplastic lesions respectively. ${ }^{[7,15]}$ 
Table 1: Distribution of ovarian lesions.

\begin{tabular}{|c|c|c|c|c|c|}
\hline \multirow{2}{*}{$\begin{array}{c}\text { Distribution } \\
\text { ovarian lesions }\end{array}$} & $\begin{array}{c}\text { Non- neoplastic } \\
\text { lesions }\end{array}$ & \multicolumn{3}{|c|}{ Neoplastic lesions } & \multirow{2}{*}{ Total } \\
\cline { 2 - 5 } & $126(69.23 \%)$ & $\begin{array}{c}\text { Benign } \\
\text { Neoplastic }\end{array}$ & $\begin{array}{c}\text { Borderline } \\
\text { Neoplastic }\end{array}$ & $\begin{array}{c}\text { Malignant } \\
\text { Neoplastic }\end{array}$ & $06(10.71 \%)$ \\
\hline $\begin{array}{c}\text { Number of cases } \\
\text { (Percentage (\%) }\end{array}$ & $\begin{array}{c}48 \\
(85.72 \%)\end{array}$ & $\begin{array}{c}02 \\
(3.57 \%)\end{array}$ & $(100 \%)$ \\
\hline Total & $126(69.23 \%)$ & \multicolumn{3}{|c|}{56} \\
\end{tabular}

Table 2: Age wise distribution of neoplastic lesions.

\begin{tabular}{|c|c|c|c|c|c|c|c|c|c|c|}
\hline \multirow{2}{*}{$\begin{array}{c}\text { Age } \\
\text { group }\end{array}$} & \multicolumn{2}{|c|}{ Surface epithelial tumor } & \multicolumn{3}{c|}{ Germ cell tumor } & \multicolumn{3}{c|}{ Sex cord stomal tumor } & Total \\
\cline { 2 - 10 } & Benign & Borderline & Malignant & Benign & Borderline & Malignant & Benign & Borderline & Malignant & 00 \\
\hline $11-20$ & 03 & 00 & 00 & 03 & 00 & 01 & 00 & 00 & 07 \\
\hline $21-30$ & 02 & 01 & 00 & 08 & 00 & 00 & 04 & 00 & 00 & 15 \\
\hline $31-40$ & 07 & 00 & 01 & 07 & 00 & 00 & 01 & 00 & 00 & 16 \\
\hline $41-50$ & 08 & 00 & 01 & 02 & 00 & 00 & 00 & 00 & 01 & 12 \\
\hline $51-60$ & 01 & 00 & 00 & 00 & 00 & 00 & 00 & 00 & 02 & 03 \\
\hline$>60$ & 02 & 01 & 00 & 00 & 00 & 00 & 00 & 00 & 00 & 03 \\
\hline TOTAL & $\mathbf{2 3}$ & $\mathbf{0 2}$ & $\mathbf{0 2}$ & $\mathbf{2 0}$ & $\mathbf{0 0}$ & $\mathbf{0 1}$ & $\mathbf{0 5}$ & $\mathbf{0 0}$ & $\mathbf{0 3}$ & $\mathbf{5 6}$ \\
\hline
\end{tabular}

Table 3: The distribution of various nonneoplastic lesions.

\begin{tabular}{|c|c|c|}
\hline Non-neoplastic lesions of ovary & Number of cases & $38.88 \%$ \\
\hline Simple Serous Cyst & 49 & $27.77 \%$ \\
\hline Endometriosis/Chocolate cyst & 35 & $12.69 \%$ \\
\hline Corpus luteal cyst & 16 & $5.55 \%$ \\
\hline Follicular cyst & 7 & $3.96 \%$ \\
\hline Congestion & 5 & $3.96 \%$ \\
\hline Normal histology & 5 & $2.38 \%$ \\
\hline Torsion & 3 & $1.58 \%$ \\
\hline Polycystic disease & 2 & $1.58 \%$ \\
\hline Ectopic gestation & 2 & $0.79 \%$ \\
\hline Vestigial/Developmental cyst & 1 & $0.79 \%$ \\
\hline Nonspecific oophoritis & 1 & $100 \%$ \\
\hline TOTAL & 126 & \\
\hline
\end{tabular}

Table 4: Spectrum of Surface epithelial tumors, Germ cell Tumors and Sex cord stromal tumors.

\begin{tabular}{|c|c|c|c|c|c|c|c|c|c|c|}
\hline \multicolumn{10}{|c|}{ Type of ovarian tumors } & \multirow[b]{3}{*}{ Total } \\
\hline \multirow[b]{2}{*}{ Benign } & \multicolumn{3}{|c|}{ Surface epithelial tumors } & \multicolumn{3}{|c|}{ Germ cell tumors } & \multicolumn{3}{|c|}{ Sex cord stromal tumors } & \\
\hline & $\begin{array}{l}\text { Histopatho- } \\
\text { logical type }\end{array}$ & $\begin{array}{l}\text { Total benign } \\
\text { cases }(n=23, \\
85.18 \%)\end{array}$ & Percentage & $\begin{array}{l}\text { Histopatho- } \\
\text { logical type }\end{array}$ & $\begin{array}{l}\text { Total benign } \\
\text { cases }(n=20 \text {, } \\
95.24 \%)\end{array}$ & Percentage & $\begin{array}{l}\text { Histopatho- } \\
\text { logical type }\end{array}$ & 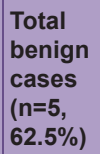 & Percentage & \\
\hline & $\begin{array}{l}\text { Serous cystade- } \\
\text { noma }\end{array}$ & 09 & $39.13 \%$ & $\begin{array}{l}\text { Mature Cyst- } \\
\text { ic Teratoma }\end{array}$ & 19 & $95 \%$ & Fibroma & 04 & $80 \%$ & \multirow[t]{3}{*}{$\begin{array}{l}48 \\
(85.72 \%)\end{array}$} \\
\hline & $\begin{array}{l}\text { Mucinous cystad- } \\
\text { enoma }\end{array}$ & 08 & $34.78 \%$ & $\begin{array}{l}\text { Mature Solid } \\
\text { Teratoma }\end{array}$ & 01 & $5 \%$ & $\begin{array}{l}\text { Sclerosing } \\
\text { stromal tumor }\end{array}$ & 01 & $20 \%$ & \\
\hline & $\begin{array}{l}\text { Serous papillary } \\
\text { cystadenoma }\end{array}$ & 03 & $13.04 \%$ & & & & & & & \\
\hline
\end{tabular}




\begin{tabular}{|c|c|c|c|c|c|c|c|c|c|c|}
\hline \multicolumn{10}{|c|}{ Type of ovarian tumors } & \multirow[b]{3}{*}{ Total } \\
\hline \multirow[b]{2}{*}{ Benign } & \multicolumn{3}{|c|}{ Surface epithelial tumors } & \multicolumn{3}{|c|}{ Germ cell tumors } & \multicolumn{3}{|c|}{ Sex cord stromal tumors } & \\
\hline & $\begin{array}{l}\text { Histopatho- } \\
\text { logical type }\end{array}$ & $\begin{array}{l}\text { Total benign } \\
\text { cases }(n=23 \text {, } \\
85.18 \%)\end{array}$ & Percentage & $\begin{array}{l}\text { Histopatho- } \\
\text { logical type }\end{array}$ & $\begin{array}{l}\text { Total benign } \\
\text { cases }(n=20 \text {, } \\
95.24 \%)\end{array}$ & Percentage & $\begin{array}{l}\text { Histopatho- } \\
\text { logical type }\end{array}$ & $\begin{array}{l}\text { Total } \\
\text { benign } \\
\text { cases } \\
(n=5, \\
62.5 \%)\end{array}$ & Percentage & \\
\hline & $\begin{array}{l}\text { Benign transitional } \\
\text { cell cystic ovarian } \\
\text { carcinoma }\end{array}$ & 01 & $4.34 \%$ & & & & & & & $\begin{array}{l}48 \\
(85.72 \%)\end{array}$ \\
\hline & Cystadenofibroma & 01 & $4.34 \% \%$ & & & & & & & \\
\hline & $\begin{array}{l}\text { Seromucinous } \\
\text { cystadenoma }\end{array}$ & 01 & $4.34 \%$ & & & & & & & \\
\hline \multirow[t]{3}{*}{ Borderline } & $\begin{array}{l}\text { Histopathologi- } \\
\text { cal type }\end{array}$ & $\begin{array}{l}\text { Total border- } \\
\text { line cases } \\
(n=2, \\
7.41 \%)\end{array}$ & Percentage & $\begin{array}{l}\text { Histopatho- } \\
\text { logical type }\end{array}$ & $\begin{array}{l}\text { Total } \\
\text { borderline } \\
\text { cases }(n=0)\end{array}$ & Percentage & $\begin{array}{l}\text { Histopatho- } \\
\text { logical type }\end{array}$ & $\begin{array}{l}\text { Total } \\
\text { borderline } \\
\text { cas- } \\
\text { es }(n=0)\end{array}$ & Percentage & Total \\
\hline & $\begin{array}{l}\text { Seromucinous } \\
\text { tumor }\end{array}$ & 01 & $50 \%$ & & & & & & & \multirow[t]{2}{*}{$\begin{array}{l}2 \\
(3.57 \%)\end{array}$} \\
\hline & Mucinous tumours & 01 & $50 \%$ & & & & & & & \\
\hline \multirow[t]{3}{*}{ Malignant } & $\begin{array}{l}\text { Histopathologi- } \\
\text { cal type }\end{array}$ & $\begin{array}{l}\text { Total malig- } \\
\text { nant cases } \\
(n=2, \\
7.41 \%)\end{array}$ & Percentage & $\begin{array}{l}\text { Histopatho- } \\
\text { logical type }\end{array}$ & $\begin{array}{l}\text { Total malig- } \\
\text { nant cases } \\
(n=1 \\
4.76 \%)\end{array}$ & Percentage & $\begin{array}{l}\text { Histopatho- } \\
\text { logical type }\end{array}$ & \begin{tabular}{|l} 
Total \\
malignant \\
cases \\
$(\mathrm{n}=3$, \\
$37.5 \%)$
\end{tabular} & Percentage & Total \\
\hline & $\begin{array}{l}\text { Seromucinous } \\
\text { cystadenocarci- } \\
\text { noma }\end{array}$ & 01 & $50 \%$ & $\begin{array}{l}\text { Dysgermi- } \\
\text { noma }\end{array}$ & 01 & $100 \%$ & $\begin{array}{l}\text { Granulosa cell } \\
\text { tumor of ovary } \\
\text { - Adult type }\end{array}$ & 03 & $100 \%$ & \multirow[t]{2}{*}{$\begin{array}{l}6 \\
(10.71 \%)\end{array}$} \\
\hline & $\begin{array}{l}\text { Endometroid } \\
\text { carcinoma }\end{array}$ & 01 & $50 \%$ & & & & & & & \\
\hline \multicolumn{10}{|l|}{ Grand total } & $56(100 \%)$ \\
\hline
\end{tabular}

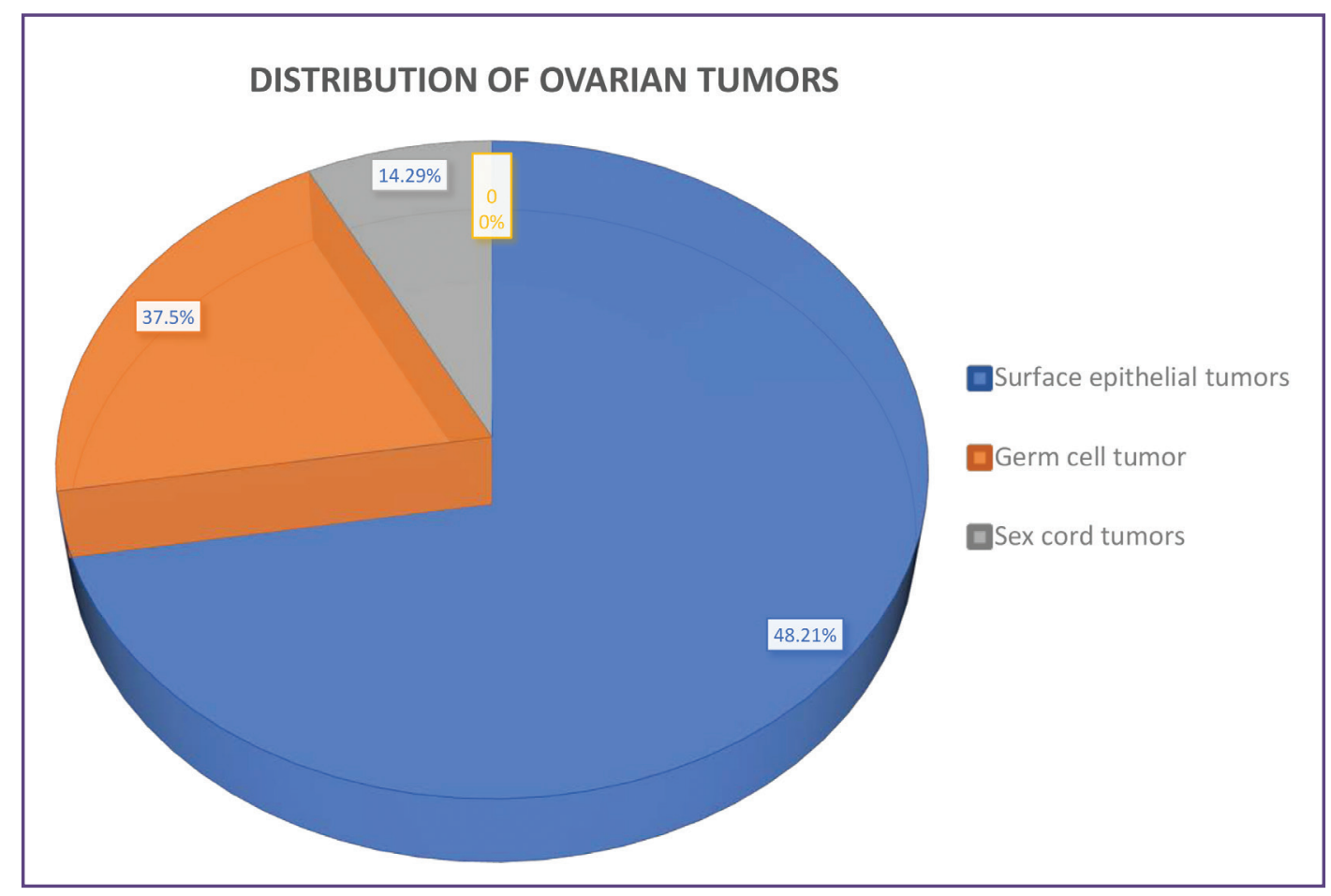




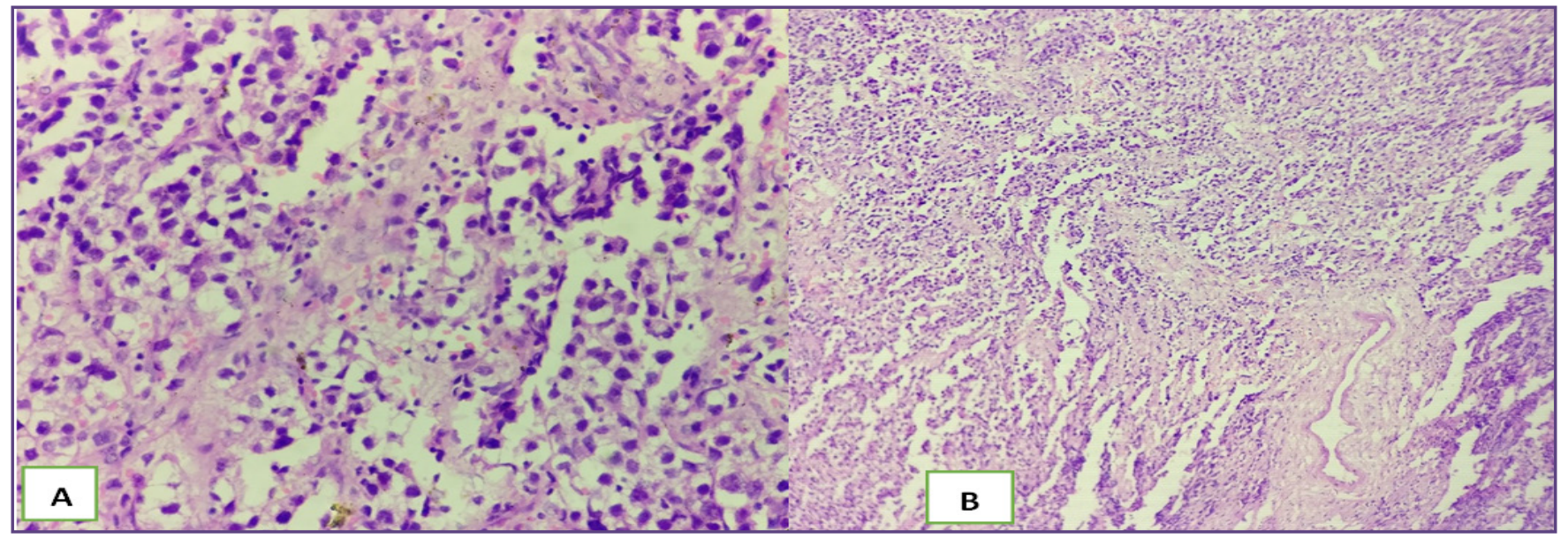

Fig. 1: DYSGERMINOMA. A: High power view of dysgerminoma shows Polygonal cells with moderate pleomorphic nuclei. B: Low power view of sheets of polygonal cells and lymphocytic infiltrate.

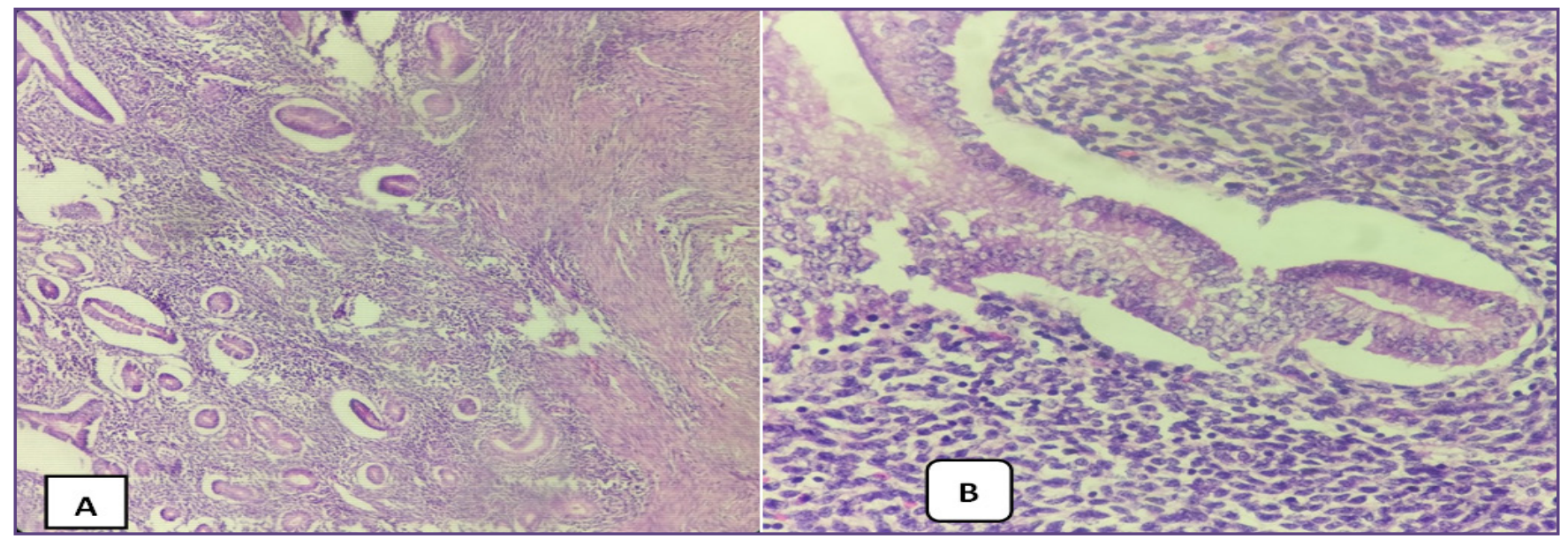

Fig. 2: ENDOMETRIOID CARCINOMA OF OVARY. A: Scanner view showing presence of endometrial glands in ovarian stroma. B: High power view of endometrial gland.

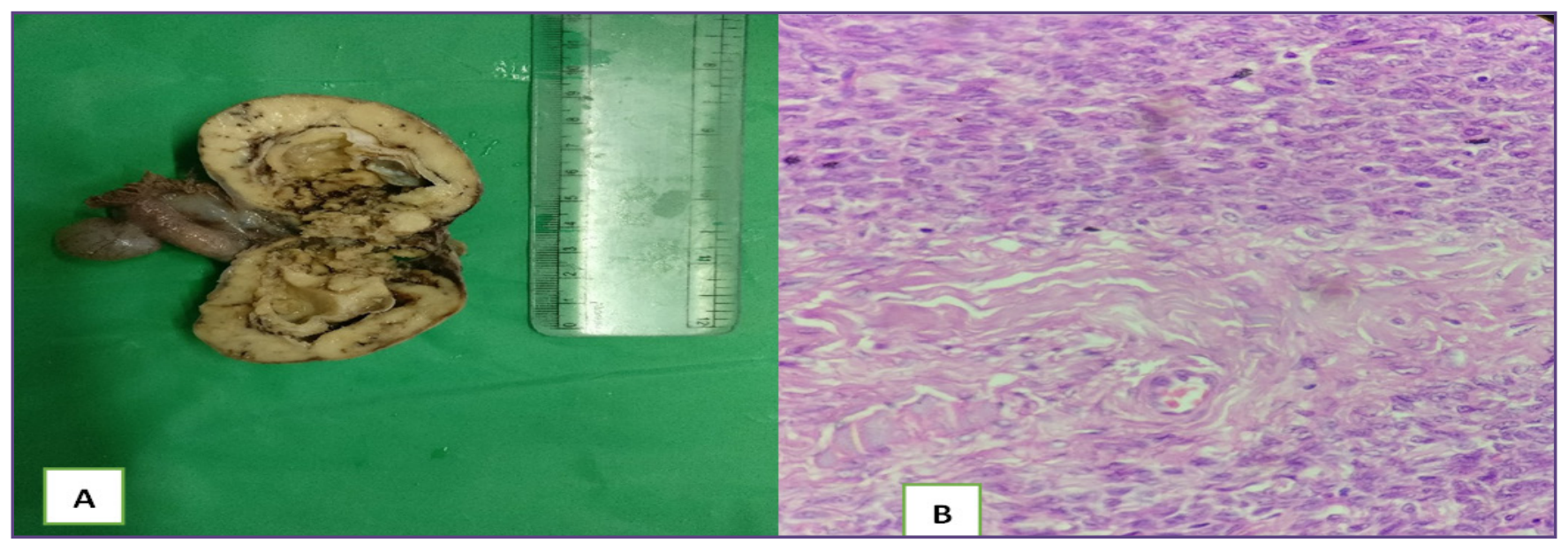

Fig. 3: GRANULOSA CELL TUMOR - ADULT TYPE A: Gross Picture of Granulosa cell Tumor, B: Microscopic Picture of Granulosa cell tumor shows Coffee bean nuclei and mitotic figures. 

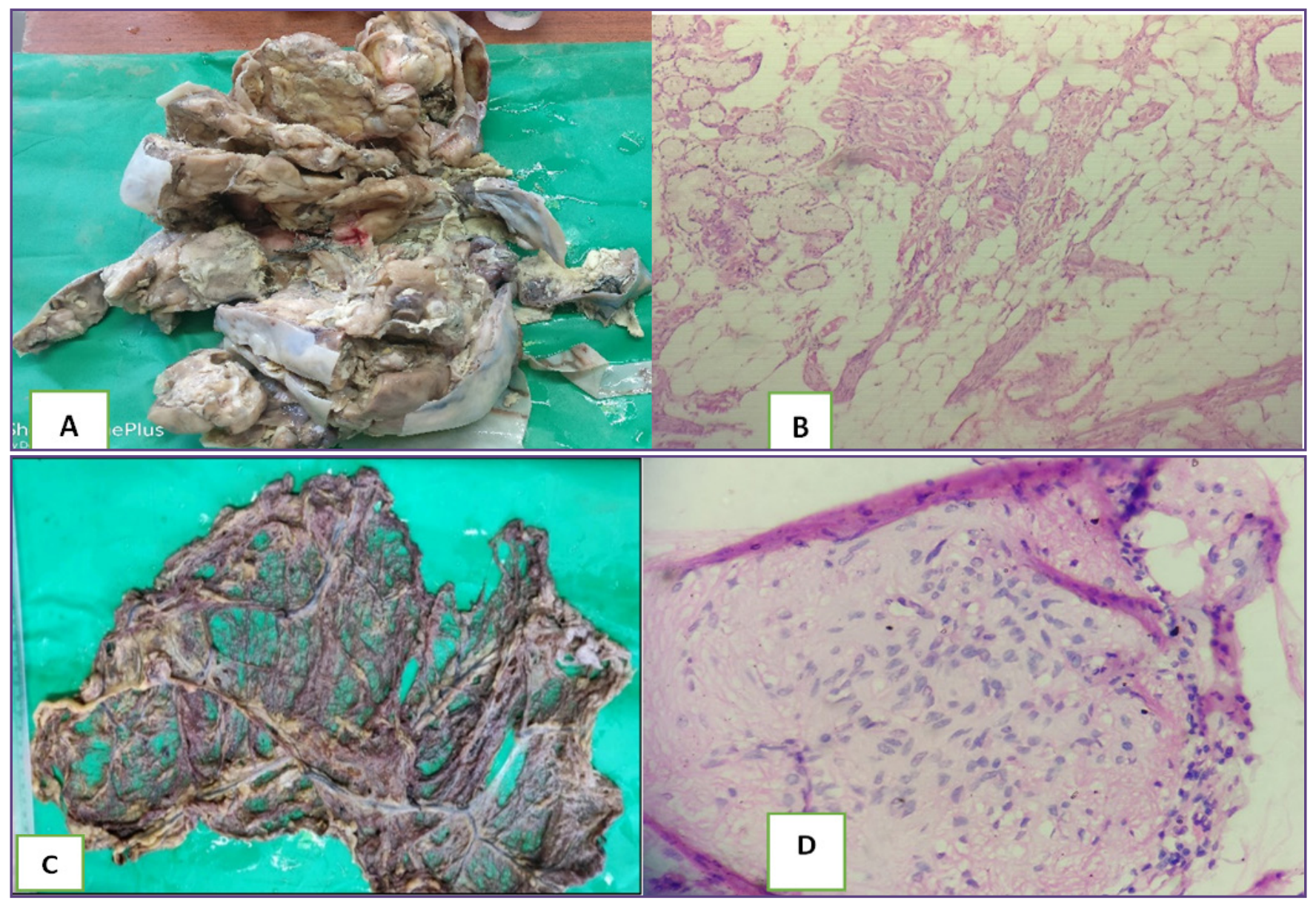

Fig. 4: MATURE SOLID TERATOMA WITH GLIOMATOSIS PERITONEI. A: Gross picture of mature solid teratoma. B: Low power view of the mature solid teratoma which contains mature adipose tissue and sebaceous glands. C: Gross picture of Peritoneum. D: Low power view shows the implantation of glial tissue in Peritoneum.

Out of total 56 neoplastic conditions, 48 cases $(85.71 \%)$ were benign, $2(3.57 \%)$ were borderline tumors and $6(10.71 \%)$ were malignant in our study. The various Indian studies done by Gupta et al, Pilli et al, Mankar and Jain et al, kanthikar S.N. et al and one sri lankan study done by M. Thirukar et al show similar distribution of neoplastic lesions

Ovarian tumor may occur at any age, including infancy and childhood. Incidence rate, however increases with age, with the greatest number of new cases being diagnosed beyond 4th and 5 th decade. In present study, benign tumors were more commonly seen in the age group 20-40 years, while malignant tumors presented commonly after 40 years of age. Similar observations were made in study done by Mondal et al ${ }^{[14]}$. In our study, the age of the patients are ranging from minimum 11 years to maximum 65 years. The age range varied in different studies. Indian Studies done by Chanu et al, and Danish et al age range is $18-83$ years, $5-72$ years respectively. ${ }^{[17,18]}$
Out of total 126 non neoplastic lesions, Simple serous cyst found most common (38.88\%) lesion followed by endometriosis (27.77\%) and corpus leuteal cyst(12.69\%). Sri lankan study done by M.Thirukumar et al shows $60.8 \%$ cases of endometriosis, $22.9 \%$ cases of corpus luteal cyst and $16.3 \%$ follicular cyst. ${ }^{[4]}$ Difference in percentage wise distribution of various non neoplastic lesions may be due to different geographical region where study conducted.

Histopathologically, surface epithelial tumors (48.21\%) were the most common category of ovarian tumors encountered, followed by germ cell tumors (37.5\%), sex cord stromal tumor (14.29\%). Various Indian studies done by Pilli et al, Kar et al, Kanthikar et al, Nirali et al and Shah et al show similar histopathological distribution of neoplastic ovarian tumors. However, there is difference in percentage of various tumors which depends upon the prevalence of this tumors in different geographic area.

From total 27 surface epithelial tumors,23(85.18\%) were benign tumors, $2(7.41 \%)$ were malignant and $2(7.41 \%)$ 
were borderline tumors in present study. Most common benign surface epithelial tumor was serous cystadenoma (39.13\%) followed by Mucinous cystadenoma (34.78\%). These findings are correlated well with study done in Nepal by Pradhan A et al in which they reported benign serous and mucinous cystadenoma $46.15 \%$ and $38.4 \%$ respectively ${ }^{[16]}$

Germ cell tumor is the second most common tumor found in our study. Total 21 cases of germ cell tumor were reported out of which $20(95.24 \%)$ were benign and $1(4.76 \%)$ was malignant. Of all 20 benign tumors, 19 (95\%) were mature cystic teratoma and one was mature solid teratoma. The mature solid teratoma was associated with gliomatosis peritonei, which is the rare condition to be associated with mature teratoma. Incidence of mature cystic teratoma is comparable to other Indian studies done by Shah et al(83.64\%) and Pradhan A et al $(92.1 \%)^{[6,16]}$

Sex cord stromal tumors constitute the $14.28 \%$ of total neoplastic lesions. Of total 8 cases, $5(62.5 \%)$ were benign, $3(37.5 \%)$ were malignant cases. All three Malignant tumors were Granulosa cell tumor- Adult type. This data is comparable to the study done by Mankar and Jain et al in which they reported $9.34 \%$ cases of sex cord stromal tumors were reported ${ }^{[13]}$

Table 5: Comparison of neoplastic tumor type with other studies.

\begin{tabular}{|c|c|c|c|c|c|c|}
\hline $\begin{array}{c}\text { Neoplastic } \\
\text { lesion }\end{array}$ & Gupta et al. ${ }^{[12]}$ & Pilli et al[9] & $\begin{array}{c}\text { Mankar and } \\
\text { Jain et al }{ }^{[13]}\end{array}$ & $\begin{array}{c}\text { Kanthikar S.N. } \\
\text { et al.. }{ }^{[2]}\end{array}$ & $\begin{array}{c}\text { M.Thirukar et } \\
\text { al. }^{[4]}\end{array}$ & \begin{tabular}{c} 
Present study \\
\hline Benign
\end{tabular} \\
\hline Borderline & $42.9 \%$ & $75.2 \%$ & $63.04 \%$ & $78.57 \%$ & $80.1 \%$ & $85.71 \%$ \\
\hline Malignant & $22.9 \%$ & $2.8 \%$ & $5.84 \%$ & $1.42 \%$ & $3.7 \%$ & $3.57 \%$ \\
\hline
\end{tabular}

Table 6: Comparison of the histopathological spectrum of neoplastic ovarian tumors.

\begin{tabular}{|l|l|l|l|l|}
\hline Study & Year & $\begin{array}{l}\text { Surface epithelial } \\
\text { tumors }\end{array}$ & Germ cell tumors & $\begin{array}{l}\text { Sex cord stromal } \\
\text { tumors }\end{array}$ \\
\hline Pilli et al ${ }^{[0]}$ & 2001 & $71 \%$ & $21 \%$ & $07 \%$ \\
\hline Kar et al ${ }^{[10]}$ & 2005 & $79 \%$ & $16 \%$ & $1.50 \%$ \\
\hline kanthikar et a[ ${ }^{[2]}$ & 2014 & $67.14 \%$ & $22.85 \%$ & $5.71 \%$ \\
\hline Nirali et al ${ }^{[1]}$ & 2015 & $73.8 \%$ & $17.8 \%$ & $6.1 \%$ \\
\hline Shah et al[6] & 2016 & $64.98 \%$ & $25.35 \%$ & $8.29 \%$ \\
\hline Present study & 2020 & $48.21 \%$ & $37.5 \%$ & $14.29 \%$ \\
\hline
\end{tabular}

\section{Conclusion}

We found that ovarian lesions affect wide variation of age starting from 11 years young patient to 65 years old patients. Non neoplastic lesions were almost double in prevalence than neoplastic lesions and more commonly found in age group of 21 to 30 years. Histopathological analysis according to WHO classification reveal that surface epithelial tumors and germ cell tumors were forms the majority of neoplastic lesions.

\section{References}

1. Malli M, Vyas B, Gupta S, Desai H. A histological study of ovarian tumors in different age groups. International Journal of Medical Science and Public Health. 2014 Mar $1 ; 3(3): 338-42$.

2. Kanthikar SN, Dravid NV, Deore PN, Nikumbh DB, Suryawanshi KH. Clinico-histopathological analysis of neoplastic and non-neoplastic lesions of the ovary: a 3-year prospective study in Dhule, North Maharashtra, India. Journal of clinical and diagnostic research: JCDR. 2014 Aug;8(8):FC04.
3. Momenimovahed Z, Tiznobaik A, Taheri S, Salehiniya H. Ovarian cancer in the world: epidemiology and risk factors. International journal of women's health. 2019;11:287.

4. Thirukumar M, Ahilan S. Histopathological pattern of ovarian lesions: a Hospital based study in Batticaloa, Sri Lanka. Journal of Diagnostic Pathology. 2018;13(1):16-21.

5. WHO classification of ovarian neoplasms. Pathology Outlines.com website. http://www.pathologyoutlines.com/ topic/ovary tumorwhoclassif.html. Accessed January 30th, 2019.

6. Shah Neerja, Raval Nisha G, Joshi Jayesh R, Agnihotri Ashok S histopathological spectrum of ovarian neoplasms- a 14 year study; Pathology and laboratory medicine 2016,vol 2 , issue 8 .

7. Sawant A, Mahajan S. Histopathological study of ovarian lesions at a tertiary health care institute. MVP Journal of Medical Science. 2017 May 22;4(1):26-9.

8. Kurman RJ, Norris HJ. Malignant germ cell tumours of the ovary. Hum Pathol.1977; 8(5):551-64. Available from: https://doi.org/10.1016/S0046-8177(77)80115-9. 
9. Pilli GS, Suneeta KP, Dhaded AV, Yenni VV. Ovarian tumours: a study of 282 cases. Journal of the Indian Medical Association. 2002 Jul;100(7):420-3.

10. Tushar, Kar \& Kar, Asaranti \& Kathagola, \& Mangalabag, Cuttack. (2005). Intra-operative cytology of ovarian tumours. Journal of Obstetrics and Gynecology of India. 55. 345-349.

11. Thakkar NN, Shah SN. Histopathological study of ovarian lesions. Int J Sci Res. 2015;4(10):1745-9.

12. Gupta N, Bisht D, Agarwal AK, Sharma VK. Retrospective and prospective study of ovarian tumours and tumour-like lesions. Indian journal of pathology \& microbiology. 2007 Jul;50(3):525-7.

13. Mankar DV, Jain GK. Histopathological profile of ovarian tumours: A twelve year institutional experience. Muller J Med Sci Res. 2015;6(2):107-1

14. Mondal SK, Banyopadhyay R, Nag DR, Roychowdhury S, Mondal PK, Sinha SK. Histologic pattern, bilaterality and clinical evaluation of 957 ovarian neoplasms: A 10-year study in a tertiary hospital of eastern India. Journal of cancer research and therapeutics. 2011 Oct 1;7(4):433.
15. Shadab S, Tadayon T. Histopathological diagnosis of ovarian mass. Journal of Pathology of Nepal. 2018 Apr $3 ; 8(1): 1261-4$

16. Pradhan A, Sinha AK, Upreti D. Histopathological patterns of ovarian tumors at BPKIHS. Health Renaissance. $2012 \mathrm{Jul}$ 28;10(2):87-97.

17. Danish F, Khanzada MS, Mirza T, Aziz S, Naz E, Khan MN. Histomorphological spectrum of ovarian tumors with immunohistochemical analysis of poorly or undifferentiated malignancies. Gomal Journal of Medical Sciences. 2012 Dec 31;10(2).

18. Chanu SM, Dey B, Raphael V, Panda S, Khonglah Y. Clinicopathological profile of ovarian cysts in a tertiary care hospital. Int J Reprod Contracept Obstet Gynecol. 2017;6:4642-5.

19. Greene MH, Clark JW, Blayney DW. The epidemiology of ovarian cancer. InSeminars in oncology 1984 Sep (Vol. 11, No. 3, pp. 209-226).

20. Harlow BL, Weiss NS, Roth GJ, Chu J, Daling JR: Casecontrol study of borderline ovarian tumors. Reproductive history and exposure to exogenous female hormones. Cancer Res 1988; 48:5849-5852.

*Corresponding author:

Dr. Deval Patel, E-201, Eye dream apartment, Science City Road, Ahmedabad, PIN: 380060

Phone: +91 91-9510991371, 91-7990045806

Email: drdeva1253@gmail.com

Date of Submission : 20/05/2020

Date of Acceptance : $27 / 08 / 2020$

Financial or other Competing Interests: None.

Date of Publication : 30/10/2020 